\title{
PENINGKATAN HASIL BELAJAR MATEMATIKA SISWA KELAS VII DENGAN MENGGUNAKAN MODEL PEMBELAJARAN THINK PAIR SHARE (TPS) DI SMP NEGERI 2 KENDARI
}

\author{
Ningsi $^{(1)}$, La Ndia $^{2)}$, Zamsir $^{3)}$ \\ ${ }^{1)}$ Alumni Jurusan Pendidikan Matematika, ${ }^{2,3}$ Dosen Jurusan Pendidikan Matematika \\ FKIP Universitas Halu Oleo, Email: sakkaningsi17@gmail.com;zamsir@uho.ac.id
}

\begin{abstract}
Abstrak
Penelitian ini dilatar belakangi oleh rendahnya hasil belajar matematika siswa kelas VII SMPN 2 Kendari. Sehingga penelitian ini bertujuan untuk meningkatkan peningkatan hasil belajar matematika siswa kelas vii dengan menggunakan model pembelajaran think pair share (TPS) di SMP Negeri 2 kendari. Subjek penelitian ini adalah seluruh siswa kelas VII $_{\mathrm{G}}$ SMP Negeri 2 Kendari yang berjumlah 35 siswa yang terdiri dari 18 laki-laki dan 17 perempuan. Hasil penelitian menunjukkan adanya peningkatan pada rata-rata hasil belajarsiswa. Dimulai dari rata-rata ketuntasan belajar siswa, presentase pada distribusi nilai pretest dengan kategori sangat tertinggi adalah $0 \%$, kategori tinggi 5,71\%, kategori sedang $68,57 \%$, kategori rendah $25,71 \%$, dan kategori sangat rendah adalah $0 \%$. Sedangkan presentase pada distribusi nilai posttest dengan kategori sangat tertinggi adalah 2,86\%, kategori tinggi $65,71 \%$, kategori sedang $31,43 \%$, kategori rendah $0 \%$, dan kategori sangat rendah adalah $0 \%$. .
\end{abstract}

Kata Kunci: think pair share, hasil belajar matematika, peningkatan

\section{IMPROVING MATHEMATICAL LEARNING OUTCOMES OF CLASS VII STUDENTS USING THINK PAIR SHARE (TPS) LEARNING MODELS IN SMPN 2 KENDARI}

\begin{abstract}
This research is motivated by the low level of mathematics learning outcomes of grade VII students of SMP 2 Kendari. So this study aims to improve the improvement of students' mathematics learning outcomes in class VI by using think pair share (TPS) learning model in SMP Negeri 2 kendari. The subjects of this study were all students of VIIG class of Public Middle School 2 Kendari which amounted to 35 students consisting of 18 men and 17 women. The results showed an increase in the average student learning outcomes. Starting from the average student learning completeness, the percentage of the pre test distribution with the very highest category is $0 \%$, high category $5.71 \%$, medium category $68.57 \%$, low category $25.71 \%$, and the very low category is $0 \%$. While the percentage in the post test distribution with the very highest category was $2.86 \%$, high category $65.71 \%$, medium category $31.43 \%$, low category $0 \%$, and very low category was $0 \%$.
\end{abstract}

Keywords: think pair share, mathematics, learning outcomes, improvement 


\section{Pendahuluan}

Belajar adalah suatu proses perubahan yang kompleks yang terjadi pada semua orang dan berlangsung seumur hidup, sejak ia masih bayi sampai ke liang lahat nanti diungkapkan Sadiman (dalam Bambang Warsito, 2008:62). SedangkanmenurutAunurrahman (2009:33) belajar adalah kegiatan berproses dan merupakan unsur yang sangat fundamental dalam penyelenggaraan jenis dan jenjang pendidikan, hal ini berarti keberhasilan pencapaian tujuan pendidikan sangat tergantung pada keberhasilan proses belajar siswa di sekolah dan lingkungan sekitarnya.Padadasarnyaujuan belajar adalah sejumlah hasil belajar yang menunjukkan bahwa siswa telah melakukan perbuatan belajar, yang umumnya meliputi pengetahuan, keterampilan dan sikap-sikap yang baru, yang diharapkan dapat dicapai oleh siswa. Hamalik (dalam Asep Jihat dan Abdul Haris, 2010:15)

Matematika merupakan salah satu ilmu yang melandasi dan menjiwai perkembangan ilmu pengetahuan dan teknologi informasi. Menurut Karyasa dkk (2011:92) ada empat sarana berpikir ilmiah, yaitu: matematika, statistika, logika dan bahasa. Oleh sebab itu pendidikan matematika perlu untuk diajarkan sejak dini sehingga diharapkan dikemudian hari generasi muda bangsa ini dapat dan mampu menguasai teknologi informasi, dan bukan hanya sebagai pengguna teknologi saja.

Guru dituntut untuk kreatif dan inovatif dalam mengajar. Karena dengan menggunakan model pembelajaran yang inovatif akan berpengaruh terhadap prestasi belajar siswa. Saat ini paradigm pembelajaran dimana guru yang menjadi pusat pembelajaran (teacher centered) sudah bergeser menjadi siswa yang menjadi pusat pembelajaran (studentcentered). Hal ini berarti bukan guru lagi yang mentransfer ilmu kepada siswa, tetapi siswa sendirilah yang mengkonstruksi pengetiannya. Dan proses pembentukan pengertian siswa secara aktif dan terus menerus (Bettencourt dalam Suparno, 1997:11).

Menurut Eggen dan Kauhak (dalam Trianto, 2007:42) dengan menerapkan model pembelajaran kooperatif maka siswa akan bekerja sama dan saling membantu untuk mencapai tujuan bersama. Penelitian menemukan bahwa diskusi mengenai masalah-masalah dapat meningkatkan pengetahuan tentang masalah tersebut serta mendorong pemahaman yang lebih dalam tentang masalah tersebut (Johnson \& Johnson dalam Slavin, 2011;307). Oleh sebab itu, diperlukan penerapan model pembelajaran kooperatif. Dengan pembelajaran kooperatif, pembelajaran akan lebih bermakna dan akan mempermudah siswa dalam menemukan dan memahami konsep-konsep yang sulit (Trianto, 2007:41).

Model pembelajaran kooperatif Think-Pair-Share (TPS) merupakan sebuah model pembelajaran yang dikembangkan oleh Frank Lyman (1985), bertujuan untuk mengajarkan siswa agar lebih mandiri dalam menyelesaikan soal-soal yang dapat membangkitkan rasa percaya diri siswa.

$$
\text { Berkenaan dengan metode }
$$
pembelajaran kooperatif Think-Pair-Share, Huda (2011: 136) mengemukakan kelebihan Think-Pair-Share sebagai berikut:1) Memungkinkan siswa untuk bekerja sendiri dan bekerja sama dengan orang lain; 2) Mengoptimalkan partisipasi siswa; 3) Memberikan kesempatan sedikitnya delapan kali lebih banyak kepada setiap siswa untuk menunjukkan partisipasi mereka kepada orang lain; 4) Bisa diterapkan untuk semua mata pelajaran dan tingkatan kelas. Sedangkan Menurut Huda (2011), kelemahan kelompok berpasangan yaitu: (1) Banyak kelompok yang akan melaporkan tugasnya pada guru; (2) Guru harus memonitor banyak kelompok; 3) Lebih sedikit ide yang muncul; 4) Jika ada perselisihan, tidak ada penengah. 


\section{Metode}

\section{Tempat dan Waktu penelitian}

Penelitian ini dilaksanakan di kelas VII $_{\mathrm{G}}$ SMPN 2 Kendari semester genap, Tahapan pengambilan data pretest dilaksanakan pada tanggal 11Mei 2015. Tahapan pelaksanaan pembelajaran dilakukan pada tanggal 12Mei 2015 sampai 26 Mei 2015. Tahapan pengambilan data posttest pada tanggal 27 Mei 2015 tahun ajaran 2014/2015.

\section{Subjek Penelitian}

Subjek penelitian ini adalah siswa kelas VII $_{\mathrm{G}}$ SMP Negeri 2 Kendari yang berjumlah 35 siswa terdiri dari 18 laki laki dan 17 perempuan. Sesuai dengan hasil pengamatan secara langsung oleh guru dan peneliti mata pelajaran matematika, di sekolah tersebut menunjukkan bahwa kelas VII $_{\mathrm{G}}$ tingkat belajarnya sangat rendah, dan hal ini berakibat pada kurang peningkatan hasil belajar siswa.

\section{Rancangan Penelitian}

Adapun tahapan pada penelitian ini adalah :

a. PerencanaanTtindakan (planning)

1) Membuat rencana pelaksanaan pembelajaran (RPP)

2) Menyusun dan mempersiapkan lembar observasi mengenai partisipasi siswa.

3) Mempersiapkan sarana dan media pembelajaran yang akan digunakan dalam setiap pembelajaran, yaitu modul dari sekolah.

4) Mempersiapkan soal tes untuk siswa yaitu tes yang akan diberikan pada akhir pembelajaran. Soal tes disusun oleh peneliti.

b. Pelaksanaan Tindakan

Tindakan ini dilakukan dengan menggunakan panduan perencanaan yang telah dibuat dan dalam pelaksanaanya bersifat fleksibel dan terbuka terhadap perubahan-perubahan. Selama proses pembelajaran berlangsung, peneliti mengajar siswa dengan menggunakan
RPP yang telah dibuat. Sedangkan peneliti yang dibantu oleh dua orang pengamat mengamati proses pembelajaran di kelas.

c. Observasi (observing)

Selama proses pembelajaran berlangsung, peneliti melakukan sebuah observasi yang meliputi di dalamnya adalah kegiatan mengajar gurudan proses belajar siswa sesuai indicator yang berlaku sesuai model pembelajaran.

d. Refleksi (reflekting)

Pelaksanaan refleksi berupa diskusi antara peneliti dan siswa. Diskusi tersebut bertujuan untuk mengevaluasi hasil belajarsiswa.

4. Data dan Sumber Data

Data dalam penelitian ini ada dua macam, yaitu data kulitatif dan data kuantitatif.

a. Jenis data : kualitatif terdiri dari hasil observasi proses pembelajaran, catatan lapangan, dan hasil dokumentasi. Sedangkan kuantitatif berasal dari hasil tes yang diisi oleh siswa pada tes awal sebelum pelaksanaan tindakan dan tesakhirsetelahpelaksanaan.

b. Sumber data : sumber data dalam penelitian ini adalah siswa.

5. Teknik Pengumpulan Data

Teknik pengumpulan data yang diterapkan adalah dengan pemberian instrument berupa tes hasil belajar matematika siswa berbentuk uraian kepada siswa

6. Teknik Analisis Data

Data dalam penelitian ini dianalisis menggunakan dua teknik statistik yaitu analisis deskriptif dan analisis inferensial.

1. Analisis deskriptif digunakan untuk menggambarkan keadaan sampel dalam bentuk persentase $(\%)$, ratarata $(\bar{x})$, median $(M e)$, modus $(M o)$, skewness, nilai maksimum $\left(x_{\max }\right)$, dan nilai minimum $\left(x_{\min }\right)$.

2. Analisis Inferensial digunakan untuk menguji hipotesis penelitian. 
Sebelum dilakukan pengujian hipotesis, terlebih dahulu dilakukan uji normalitas untuk mengetahui apakah data yang akan diuji berasal dari populasi normal atau tidak. Data yang digunakan dalam uji normalitas dan uji-t berbentuk skorNormalized Gain (N-gain). Gain adalah selisih antara nilai posttest dan pretest, gain menunjukkan peningkatan pemahaman atau penguasaan konsep siswa setelah pembelajaran dilakukan guru.

Rumus Normalized Gain

NormalizedGain $=\frac{S_{\text {post }}-S_{\text {pre }}}{S_{\max }-S_{\text {pre }}}$

Keterangan :

$S_{\text {post }}=$ Skor post test,

$S_{\text {pre }}=$ Skor pre test,

$S_{\max }=$ Skor maksimum.

Dengan kriteria nilai Normalized Gain sebagai berikut:

\section{Kriteria NormalizedGain}

\begin{tabular}{|l|l|}
\hline Perolehan Normalized Gain & Kriteria \\
\hline Normalized Gain $>0,70$ & Tinggi \\
\hline $0,30 \leq$ Normalized Gain $\leq 0,70$ & Sedang \\
\hline Normalized Gain $<0,30$ & Rendah \\
\hline
\end{tabular}

Archambault (Duda, 2010:32).

\section{Indikator Keberhasilan}

Berdasarkan dari penelitian yang telah dilakukan, penelitian berhasil apabila persentase ketuntasan belajar mencapai 85\% siswa mencapi KKM yang telah ditentukan oleh sekolah yaitu 65 .

\section{Hasil dan Pembahasan}

\section{Hasil Analisis Deskriptif}

Tabel 4.1.

Rekapitulasi Pelaksanaan Pembelajaran Model TPS

\begin{tabular}{|l|c|c|}
\hline Pertemuan & Skor Total & Persentase (\%) \\
\hline Pertama & 15 & 68,18 \\
\hline Kedua & 17 & 77,27 \\
\hline Ketiga & 15 & 68,18 \\
\hline Keempat & 18 & 81,81 \\
\hline Kelima & 22 & 100 \\
\hline
\end{tabular}

Skor maksimal $=22$

Berdasarkan hasil observasi terhadap pelaksanaan pembelajaran matematika dengan menggunakan modelTPS pada materi statistika, keberhasilan pengelolaan pembelajaran pada pertemuan pertama sudah cukup baik dengan tingkat keberhasilan sebesar 68,18\%.Pelaksanaan pembelajaran pada pertemuan kedua mengalami peningkatan dibanding pertemuan pertama. Tingkat keberhasilan pembelajaran mencapai $77,27 \%$.

\section{a. Hasil Observasi Pelaksanaan Pembelajaran dengan Model Pembelajaran TPS oleh Guru}

Hasil observasi pelaksanaan pembelajaran yang dilakukan guru pada model pembelajaran TPS dapat terlihat dalam tabel 4.1.

\section{6}


b. Hasil Observasi Aktivitas Siswa dalam Pelaksanaan Pembelajaran dengan Model Pembelajaran TPS
Hasil observasi aktivitas siswa dengan pelaksanaan pembelajaran dengan model pembelajaran TPSdapat terlihat dalam tabel4.2.

Tabel 4.2

Rekapitulasi Keaktifan Siswa pada Model PembelajaranTPS

\begin{tabular}{|l|c|c|}
\hline Pembelajaran & Skor Total & Persentase \\
\hline Pembelajaran I & 45 & 60 \\
\hline Pembelajaran II & 47 & 62,66 \\
\hline Pembelajaran III & 52 & 69,33 \\
\hline Pembelajaran IV & 53 & 70,66 \\
\hline Pembelajaran V & 56 & 74,66 \\
\hline
\end{tabular}

Skor maksimal $=75$

Hasil observasi aktivitas siswa dalam pelaksanaan pembelajaran matematika menggunakan model TPS pada materi statistika. Pada pertemuan pertama ketercapaian dari seluruh aspek yang diamati adalah $60 \%$ yang berarti bahwa keaktifan siswa pada pertemuan pertama tergolong cukup. Pada pertemuan pertama siswa masih kurang menyadari tugas dan tanggung jawab mereka dalam kelompok. Mereka cenderung saling berharap kepada teman dan guru, sehingga kerjasama dalam kelompokberjalan kurang baik.Beberapa siswa juga belum mampu menemukan sendiri penyelesaian suatu masalah yang diberikan. Pada pertemuan kedua ketercapain dari seluruh aspek yang diamati mengalami peningkatan menjadi $62,66 \%$. Hal ini terlihat dengan membaiknya keterlibatan siswa dalam kelompoknya.

Pertemuan ketiga sampai kelima, ketercapaian aspek yang diamati berturutturut adalah69,33\%, 70,66\%, dan 74,66\%. Secara umum, ketercapaian keseluruhan aspek yang diamati pada pertemuan ketiga sampai kelima mengalami peningkatan jika dibandingkan dengan pelaksanaan pada pertemuan pertama dan kedua. Pada pertemuan ketiga sampai kelima ini siswa mulai terbiasa belajar secara berkelompok dengan menggunakan model TPS.

\section{c. Analisis Deskriptif HasilBelajar MatematikaSiswa berdasarkan Hasil Pre Test dan Post Test}

Distribusi nilai pretest merupakan distribusi nilai yang diperoleh siswa sebelum adanya perlakuan berupa pembelajaran menggunakan model TPS. Hasil pre test menggambarkan kemampuan awal hasil belajar matematika siswa. Sementara distribusi nilai post test merupakan distribusi nilai yang diperoleh siswa setelah pembelajaran dengan model TPS yang menggambarkan hasil belajar matematika siswa setelah pembelajaran dengan model TPS. Berdasarkan hasil analisis deskriptif dengan olahan SPSS 16,0 diperoleh datahasilbelajar matematika siswa seperti pada table 4.3 berikut. 
Tabel 4.3.

Analisis Deskriptif Pretest HasilBelajar MatematikaSiswa

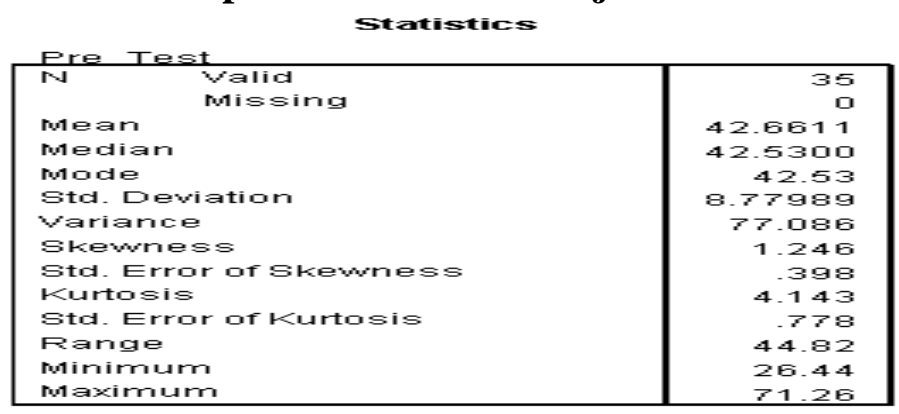

\section{Sumber: Data Primer Diolah Dengan SPSS}

Hasil pre test menunjukkan bahwa nilai terendah yang dicapai siswa adalah 26,44 dan nilai tertinggi yang diperoleh siswa adalah 71,26 . Nilai rata-rata pada hasil tes awal diperoleh sebesar 42,66 (pembulatan sampai dua angka di belakang koma). Hal ini menggambarkan bahwa secara keseluruhan kemampuan hasil belajar matematika siswa tergolong masih rendah, Median atau nilai tengah sebesar 42,53. Modus atau nilai yang sering muncul yaitu 42,53. Nilai ini menunjukkan bahwa sebagian besar siswa memiliki tingkat hasilbelajarmatematika siswa masih rendah.
Nilai rata-rata (42.66), median $(42,53)$ dan modus (42,53) yang saling berdekatan menggambarkan bahwa sebaran data normal. Nilai median dan modus yang lebih kecil dari rata-rata menggambarkan bahwa lebih banyak siswa yang kemampuanya berada di bawah rata-rata Standar deviasi sebesar 8,77 dan varians sebesar 77,08. Nilai varians ini menunjukkan bahwa keragaman hasilbelajar matematika siswa pada pretest tidak begitu besar atau tingkat kehomogenan dari data tersebut cenderung besar.

Tabel 4.3.

Analisis Deskriptif Posttest HasilBelajar MatematikaSiswa

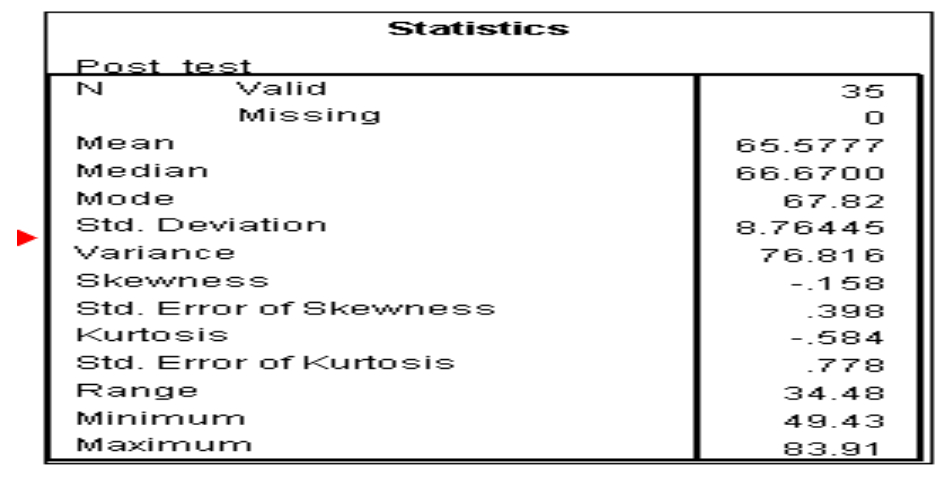

Hasil post test di atas menunjukkan bahwa nilai terendah yang dicapai siswa adalah 49,53 dan nilai tertinggi yang diperoleh siswa adalah 83,91.Nilai rata-rata pada hasil post testdiperoleh sebesar 65,58 (pembulatan sampai dua angka di belakang koma). Hal ini menggambarkan bahwa secara keseluruhan hasilbelajar matematika siswa tergolong tinggi. Median atau nilai tengah sebesar 66,67. Modus atau nilai yang sering muncul yaitu 67,82. Nilai ini menunjukkan bahwa sebagian besar siswa memiliki tingkat hasilbelajar matematika siswa sudah dalam ketegori tinggi. Nilai rata-rata $(65,58)$, median $(66,67)$ dan modus $(67,82)$ yang saling berdekatan menggambarkan bahwa sebaran data normal. Nilai median dan modus yang lebih 
besar dari rata-rata menggambarkan bahwa lebih banyak siswa yang kemampuanya berada di atas rata-rata. Standar deviasi sebesar 8,76 dan varians sebesar 76,85. Nilai varians ini menunjukkan keragaman hasilbelajar matematika siswa pada post test.
Adapun distribusi data hasil pretestdan post test hasilbelajarmatematika dapat dilihat pada tabel 4.5 dan 4.6berikut.

Tabel 4.5.

Distribusi DataPretest

\begin{tabular}{|l|l|l|}
\hline Predikat & Frekuensi & Persentase \\
\hline Sangat Tinggi & 0 & 0 \\
\hline Tinggi & 2 & 5.71 \\
\hline Sedang & 24 & 68.57 \\
\hline Rendah & 9 & 25.71 \\
\hline Sangat Rendah & 0 & 0 \\
\hline
\end{tabular}

Tabel 4.5dangambar 4.1 di atas memberikan gambaran bahwa hasil belajar matematika siswa sebelum pembelajaran dengan model TPSmasih rendah. Siswa yang memiliki hasilbelajar matematika sebelum pembelajaran menggunakan model pembelajaran TPS yang tergolongrendah sebanyak 9 orang atau $25,71 \%$, yang berarti bahwa kurang dari setengah jumlah siswa memiliki hasilbelajarrendah. Siswa yang memiliki hasilbelajar matematika yang tergolong sedang sebanyak 24orang atau $68,57 \%$, dan siswa pada kategori tinggi hanya 2 orang atau $5,71 \%$. Sementara berdasarkan hasil pre test ini belum ada siswa yang memiliki hasil belajar matematika pada ketegori sangat tinggi.

Tabel 4.6. Distribusi DataPost Test

\begin{tabular}{|l|l|l|}
\hline Predikat & Frekuensi & Persentase \\
\hline Sangat Tinggi & 1 & 2.86 \\
\hline Tinggi & 23 & 65.71 \\
\hline Sedang & 11 & 31.43 \\
\hline Rendah & 0 & 0.00 \\
\hline Sangat Rendah & 0 & 0.00 \\
\hline
\end{tabular}

Tabel 4.6dangambar 4.1 di atas memberikan gambaran bahwa hasil belajar matematika siswa setelah pembelajaran dengan model TPSsudah pada kategori tinggi. Siswa yang memiliki hasilbelajarmatematika setelah pembelajaran menggunakan model pembelajaran TPS yang tergolong sangat tinggi sebanyak 1 orang atau $2,86 \%$, siswa yang memiliki hasil belajar matematika yang tergolong tinggi berjumlah 23 orang atau $65,71 \%$, ini berarti sudah banyak siswa yang mempunyai hasil belajar matematika dengan baik. Siswa yang memiliki hasil belajar dalam ketegori sedang berjumlah 11 orang atau $31,43 \%$ yang artinya siswa ini belum mempunyai hasil belajar matematika yang baik. Sementara itu setelah pembelajaran dengan model TPS sudah tidak ada siswa yang berada dalam kategori rendah maupun kategori sangat rendah.

Berdasarkan tabel 4.5, dan 4.6 maka dapat dibuat grafik distribusi data pretestdan post test sebagai berikut. 


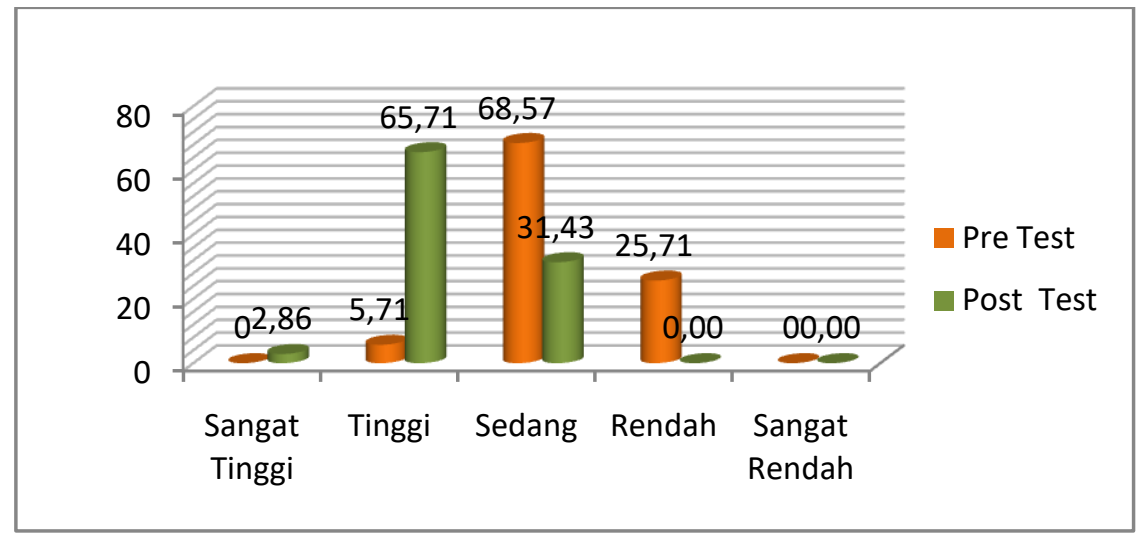

Gambar 1.DistribusiNilai Pre Test dan Post Test

Tabel 4.6dangambar $4.1 \mathrm{di}$ atas memberikan gambaran bahwa hasil belajar matematika siswa setelah pembelajaran dengan model TPSsudah pada kategori tinggi. Siswa yang memiliki hasilbelajarmatematika setelah pembelajaran menggunakan model pembelajaran TPS yang tergolong sangat tinggi sebanyak 1 orang atau $2,86 \%$, siswa yang memiliki hasil belajar matematika yang tergolong tinggi berjumlah 23 orang atau $65,71 \%$, ini berarti sudah banyak siswa yang mempunyai hasil belajar matematika dengan baik. Siswa yang memiliki hasil belajar dalam ketegori sedang berjumlah 11 orang atau $31,43 \%$ yang artinya siswa ini belum mempunyai hasil belajar matematika yang baik. Sementara itu setelah pembelajaran dengan model TPS sudah tidak ada siswa yang berada dalam kategori rendah maupun kategori sangat rendah.

Hasil belajar matematika siswa dibandingkan dengannilai KKM dapat dilihat pada tabel 4.4 berikut.

\section{Tabel 4.7.Ketuntasan Siswa Berdasarkan Nilai KKM}

\begin{tabular}{|l|c|c|}
\hline \multicolumn{1}{|c|}{ Hasil } & Tuntas & Tidak Tuntas \\
\hline Pre Test & 2 & 33 \\
\hline Post Test & 23 & 12 \\
\hline
\end{tabular}

Berdasarkan tabel 4.4 di atas, kemampuan hasil belajar matematika siswa sebelum pembelajaran dengan model TPS pada hasil pre test hanya terdapat 2 orang siswa yang mencapai nilai KKM dan 33 orang siswa dibawah nilai KKM. Sedangkan pada hasil post test terdapat 23 orang siswa telah mencapai nilai KKM dan 12 orang siswa masih dibawah nilai KKM. Ini menunjukkan bahwa terjadi peningkatan hasil belajar matematika siswa setelah diajar dengan menggunakan model pembelajaran TPS.

\section{d. Analisis Deskriptif Pengaruh $\left(\mathbf{N}_{\text {gain }}\right)$ HasilBelajar MatematikaSiswa}

1) Distribusi data hasil penelitian hasilbelajar matematika siswa

Skor pre test dan post test yang diperoleh diolah menjadi gain ternormalisasi agar terlihat peningkatan yang diperoleh oleh siswa. Penskoran diberikan sesuai dengan pedoman penskoranhasilbelajarmatematika. Data hasil penelitian, menghasilkan data klasifikasi 
normalized gain yang disajikan pada tabel berikut.

Tabel 4.8

Daftar Distribusi Frekuensidan Klasifikasi Normalized Gain Hasil Belajar Matematika Siswa

\begin{tabular}{|c|c|c|c|}
\hline Normalized Gain & Klasifikasi & F & $\begin{array}{c}\text { Frekuensi Relatif } \\
(\mathbf{\%})\end{array}$ \\
\hline $\mathrm{G}<0,30$ & Rendah & 11 & 31.43 \\
\hline $0,30 \leq \mathrm{G} \leq 0,70$ & Sedang & 23 & 65.71 \\
\hline $\mathrm{G}>0,70$ & Tinggi & 1 & 2.86 \\
\hline$\sum$ & & $\mathbf{3 5}$ & $\mathbf{1 0 0}$ \\
\hline
\end{tabular}

Tabel 4.8di atas, menunjukkan nilai normalized gain paling banyak terdapat pada klasifikasi yang "sedang" yakni pada interval $0,30 \leq \mathrm{G} \leq 0,70$ dengan jumlah siswa 23 orangdan terdapat masing-masing 11dan 1 orang siswa berada pada klasifikasi rendah dan tinggi. Ini menunjukkan bahwa, lebih dari setengah jumlah siswa memiliki peningkatan hasilbelajaryang sedang, dengan persentase sebesar $65,71 \%$. Hal ini berarti siswa mempunyai hasil belajar yang baik.

Berdasarkantabel

4.8dapatdibuatgrafikyangmenunjukanklasifi kasinormalized gainhasilbelajarmatematikasiswa, sepertidibawahini

Distribusi N_Gain
Rendałedanginggi

Gambar4.2. Grafik Frekuensi Data KlasifikasiNormalizedGain Hasil BelajarMatematikaSiswa

2) Ukuran statistik hasilbelajar hasilbelajar matematikasiswa.. Berdasarkan matematika siswa hasil analisis deskriptif denganolahan SPSS diperoleh data hasilbelajar matematikasiswa

Ukuran statistik data diperoleh dari yang disajikan pada tabel 4.8 berikut.

analisis data gain ternormalisasi hasil tes

Tabel 4.9.

Statistik Deskriptif HasilBelajarMatematika

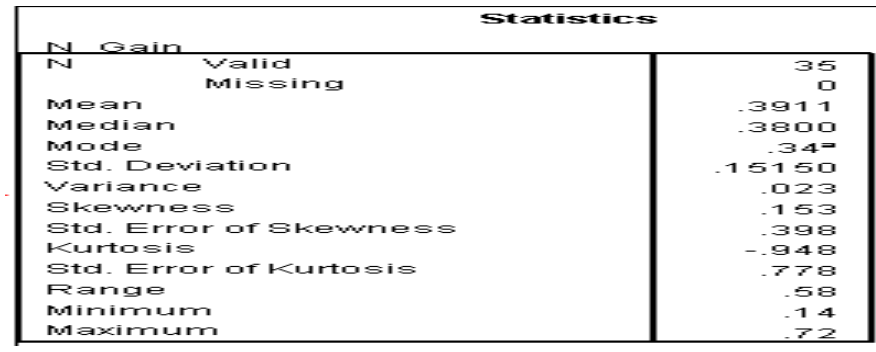

Sumber: Data Primer Diolah Dengan SPSS 
Berdasarkan hasil analisis deskriptif hasilbelajar matematika siswa diperoleh peningkatan terendah 0.14 yang berarti bahwa masih terdapat siswa yang belum mempunyai hasil belajar matematika yang baik. Peningkatan tertinggi yaitu 0.72 , nilai ini menunjukkan bahwa siswa tersebut telah mempunyai hasil belajar matematika yang sangat baik. Nilai rata-rata peningkatan hasil belajar matematika siswa 0,39 berada pada kategori sedang Modus atau nilai yang sering muncul yaitu 0.34 , dan median atau nilai tengah yaitu 0,38 . Nilai ini menunjukkan bahwa sebagian besar siswa memiliki hasilbelajar pada kategori sedang. Nilai rata-rata $(0,39)$, median $(0,34)$ dan modus $(0,38)$ yang saling berdekatan menggambarkan bahwa sebaran data normal. Nilai median dan modus yang lebih kecil dari rata-rata menggambarkan bahwa lebih banyak siswa yang hasil belajarnya berada di bawah rata-rata. Standar deviasi sebesar 0.15 dan varians sebesar 0.02 . Nilai varians ini menunjukkan tingkat keragaman hasil belajar matematika siswa.

Nilai rata-rata normalized gain sebesar 0.39, yang berarti bahwa keseluruhan hasil belajar matematika siswa tergolong sedang, artinya keseluruhan siswa mempunyai hasil belajar yang baik. Nilai rata-rata normalized gain ini menunjukkan bahwa model pembelajaran TPS memberikan peningkatan yang baik pada hasil belajar matematika siswa.

\section{e. Hasil Analisis Inferensial}

Tahap selanjutnya dalam analisis data adalah analisis inferensial. Melalui analisis inferensial kita dapat mengetahui apakah hipotesis dalam penelitian ini diterima atau ditolak. Dalam analisis inferensial, terdapat beberapa tahap analisis yang menjadi prasyarat untuk melakukan analisis uji hipotesis yaitu analisis uji normalitas data. Analisis uji normalitas data dimaksudkan untuk mengetahui apakah data yang diperoleh berdistribusi normal atau tidak, setelah melalui syarat uji normalitas maka dilanjutkan dengan uji hipotesis. Berikut penjabaran dari tahap analisis inferensial.

\section{a. Uji Normalitas}

Uji normalitas data dalam penelitian ini menggunakan statistik uji KolmogorovSmirnov dengan bantuan aplikasi SPSS. Dalam analisis ini akan digunakan skor Normalized Gain.Hasil perhitungannya disajikan dalam tabel 4.7 berikut.

Tabel 4.10. Uji Normalitas data dengan Kolmogorov Smirnov

\begin{tabular}{|c|c|c|}
\hline & & VAR00001 \\
\hline $\mathbf{N}$ & & 35 \\
\hline \multirow[t]{2}{*}{ Normal Parameters } & Mean & .3911 \\
\hline & Std. Deviation & .15150 \\
\hline \multirow[t]{3}{*}{ Most Extreme Differences } & Absolute & .102 \\
\hline & Positive & .102 \\
\hline & Negative & -.096 \\
\hline Kolmogorov-Smirnov $Z$ & & .605 \\
\hline Asymp. Sig. (2-tailed) & & 857 \\
\hline
\end{tabular}

\section{Sumber: Data Diolah Dengan SPSS}

Tabel 4.10 di atas menunjukkan bahwa nilai KS 0,605 dan nilai $P_{\text {value }} 0,857$ $>\frac{1}{2} \alpha \quad$ (dengan $\alpha=0,05$ ), sehingga $\mathrm{H}_{0}$ diterima. Dengan demikian, dapat disimpulkan bahwa data $N$ gainhasilbelajarmatematika siswa berdistribusi normal.

\section{b. Pengujian Hipotesis}

Pengujian hipotesis menggunakan rumus uji-t satu sampel (one-sample test). Rumusan hipotesis statistik yang diuji adalah:

$$
\mathrm{H}_{0}: \mu=0 \text { lawan } \mathrm{H}_{1}: \mu>0
$$


Dengan : $\mu=$ nilai rata-rata $N$ -

Gain hasilbelajar matematika siswa

Kriteria pengujian yang digunakan adalah: jika nilai setengah $P_{\text {value }}$ lebih kecil dari $\alpha(\alpha=0,05)$; maka $\mathrm{H}_{1}$ diterima, dalam hal lainnya $\mathrm{H}_{0}$ ditolak. Hasil analisis uji hipotesis disajaikan seperti tabel 4.10 berikut.

Table 4.11.

Uji Hipotesis dengan uji t satu sampel

\section{One-Sample Test}

\begin{tabular}{|c|c|c|c|c|c|c|c|}
\hline & \multicolumn{7}{|c|}{ Test Value $=0$} \\
\hline & \multirow[b]{2}{*}{ t } & \multirow[b]{2}{*}{ Df } & \multirow{2}{*}{$\begin{array}{l}\text { Sig. } \\
\text { tailed) }\end{array}$} & \multirow{2}{*}{ (2- } & \multirow{2}{*}{$\begin{array}{l}\text { Mean } \\
\text { Difference }\end{array}$} & \multicolumn{2}{|c|}{$\begin{array}{l}95 \% \text { Confidence Interval } \\
\text { of the Difference }\end{array}$} \\
\hline & & & & & & Lower & Upper \\
\hline $\begin{array}{l}\mathrm{N} \text { _G } \\
\text { ain }\end{array}$ & 15.274 & 34 & .000 & & .39114 & .3391 & .4432 \\
\hline
\end{tabular}

Sumber: DataDiolah Dengan SPSS

Tabel 4.11menunjukkanbahwa nilai $\mathrm{t}$ hitung lebih besar dari nilai $t$ tabel $(0,05 ; 35)$ yakni $\left(t_{\text {hitung }}=15,274>\quad t_{\text {tabel }}=\right.$ 1,691)sehingga $\mathrm{H}_{0}$ ditolak. Sehingga dapat disimpulkan bahwahasilbelajar matematika siswa yang diajar dengan menggunakan model pembelajaran TPS mempunyai pengaruh yang signifikan.

\section{Pembahasan}

Berdasarkan uraian analisis data hasil penelitian dan pengujian hipotesis di atas, berikut ini dikemukakan pembahasan terhadap beberapa temuan sehubungan dengan pengaruhhasilbelajar matematika siswa, berdasarkan model pembelajaran yang digunakan.

Pelaksanaan penelitian ini menggunakan satu kelas dengan menerapkanmodel pembelajaranTPS dan dengan pendekatan saintifik. Sebelum penerapan model pembelajaran TPS, siswa diberi pretest,kemudian diberi posttest setelah model pembelajaran selesai dilaksanakan.

Total pertemuan dalam penelitian ini yaitu sebanyak 7 kali pertemuan, dengan 5 kali pertemuan digunakan untuk proses pembelajaran dan 2 kali pertemuan digunakan untuk tes hasilbelajarmatematika siswa yakni, pretest dan posttest. Pembelajaran yang dilaksanakan memiliki lima tahap pembelajaran yaitu: orientasi siswa pada masalah, mengorganisasi siswa untuk belajar, membimbing kelompok atau individu, menyajikan hasil karya, dan menganalisis dan mengevaluasi pemecahan masalah. Lima tahap ini mengikuti langkahlangkah pembelajaran dengan pendekatan saintifik yakni mengamati, menanya, mengeksplorasi, mengasosiasi dan mengkomunikasikan.Rangkaian tahap-tahap dalam pembelajaran ini sangat menekankan kepada siswa agar mampu menyelesaikan suatu masalah dengan idenya sendiri, sehingga materi pelajaran dapat mudah diingat oleh siswa dan tidak mudah dilupakan serta dapat melatih dan meningkatkan hasilbelajarsiswa dalam memecahkan masalah matematika.

\section{Pelaksanaanproses}

pembelajaran,pertama-tama dilakukan kegiatan pendahuluan, yang meliputi pemberian apersepsi, pemberian motivasi dan penyampaian tujuan pembelajaran, kemudian dilakukan pembagian kelompok yang heterogen. Dalam proses pembelajaran di kelas ini, siswa dibagi menjadi 17 kelompok dengan tiap kelompok 
beranggotakan

siswadansatukelompokberanggotakan

orang. Kemudian padasetiap siswa diberikan bahan ajar dan LKS untuk dikerjakan secara berkelompok. Pada tahap ini, guru berperan memberi pengarahan dan bimbingan kepada siswa melalui penjelasan atau pertanyaan yang mengarah pada penyelesaian masalah bila diminta langsung oleh siswa dengan memanfaatkan media pembelajaran. Setelah semua kelompok telah mengerjakan LKS yang diberikan sesuai dengan waktu yang ditetapkan, beberapa siswa dipilih mewakili kelompoknya untuk mempresentasekan hasil kerja kelompoknya dan ditanggapi oleh kelompok lain. Di akhir pertemuan, guru mengajak siswa untuk membuat kesimpulan dari materi yang telah dipelajari. Kemudian guru memberikan tes evaluasi yang dikerjakan secara individu. Terakhir, guru memberikan tugas untuk dikerjakan di rumah secara individu.

Awal pelaksanaan pembelajaran mengalami sedikit hambatan. Siswa membutuhkan waktu untuk menyesuaikan diri dengan pembelajaran yang baru diterapkan di kelas, dan guru juga masih menyesuaikan dengan kondisi kelas yang ada.Dari awal kelompok siswa memang sudah terbentuk, tetapi interaksi dalam kelompok ini tidak terjadi. Siswa masih kurang aktif dalam kelompok sehingga penyerapan materi dan penyelesaian masalah masih kurang efektif. Masalah pemanfaatan waktu menjadi perhatian penting untuk pertemuan berikutnya.

Pembelajaran pada pertemuan kedua sampai keempat pembelajaran sudah berjalan dengan baik. Siswa dan guru sudah bisa beradaptasi dengan kondisi yang ada. Meskipun beberapa siswa masih mengalami kesulitan dalam mengolah informasi dari LKS dan sumber belajar lainnya, sehingga siswa tersebut belum mampu menemukan sendiri penyelesaian dari masalah yang diberikan. Setelah guru memberi arahan dan bimbingan, siswa mulai mengerti dengan pembelajaranTPS. Guru dan siswa sudah menunjukkan sikap yang antusias dalam proses pembelajaran. Siswa juga mulai merasa bertanggung jawab dalam kelompok belajarnya, untuk mengerjakan tugas-tugas kelompo. Pada pertemuan kelima proses pembelajaran sudah berjalan maksimal. Siswa sudah terbiasa dan dapat melaksanakan model pembelajaran yang diterapkan di dalam kelas dengan baik

Berdasarkan hasil pengamatan guru terhadap sikap siswa selama pembelajaran, pada pertemuan pertama dan keduasiswa masih nampak ragu - ragu dalam bertindak dan menyampaikan pendapat. Selanjutnya mulai pertemuan ketiga sikap siswa sudah mulai aktif. Sudah banyak siswa menunjukkan sikap toleransi , disiplin, dan rasa ingin tahu. Siswa sudah mulai bertanggung jawab terhadap tugas yang diberikan serta teliti dalam menyelesaikan masalah-masalah yang diberikan. Salah satu sikap siswa yang masih menjadi kendala hingga pertemuan kelima adalah sikap tanggung jawab. Sikap kurang percaya diri siswa masih sangat nampak, ini terlihat pada saat siswa mengerjakan soal-soal yang ada dalam Lembar Kerja Siswa.

Dari proses pembelajaran juga diketahui beberapa siswa sudah memiliki keterampilan sosial yang baik. Hal ini ditunjukkan dari beberapa hal antara lain: (1) cara bertanya siswa yang sopan kepada guru maupun temannya, (2) siswa menghargai pendapat yang berbeda (3) siswa dapat memberikan ide atau pendapat yang baik, (4) siswa menjadi pendengar yang baik, dan (5) siswa dapat bekerja sama dengan teman yang lain. Walaupun ada beberapa siswa yang kadang kurang aktif dalam kelompok belajar, karena sesungguhnya hal itu adalah kebiasaan dan karakter yang sudah dimiliki oleh siswa yang bersangkutan. Selain itu dari segi keterampilan dalam menyelesaikan masalah, siswa sudah cukup bagus. Ini terlihat dari, siswa sudah dapat memilih dan menerapkan konsep yang sesuai untuk penyelesaian suatu masalah. 
Sebelum adanya perlakuan berupa model pembelajaran TPS, terlebih dahulu siswa diberikan tes awal (pretest) dengan tujuan untuk mengetahui hasilbelajarmatematika awal siswa. Setelah pretest, kemudian siswa diberi perlakuan berupa model pembelajaran TPSdengan tujuan untuk melihatpengaruh model pembelajaranTPSterhadaphasilbelajar

matematika siswa lalu dilanjutkan dengan tes akhir (posttest).Jumlah soal yang digunakan untuk pretestdan posttest masingmasing 7 nomor.Skor pretest dan posttest diolah menjadi nilai normalized gain.

Rata-rata normalized gain yang diperoleh merupakan gambaran peningkatanhasilbelajarmatematika siswa yang diajar dengan model pembelajaran TPS. Hasil analisis data diperoleh rata-rata nilai pre test adalah 42,66 dan rata-rata nilai post test adalah 65,58. Ini menunjukan adanya pengingkatan hasil belajar matematika siswa setelah pembelajaran dengan model TPS. Nilai normalized gainhasilbelajar matematikasiswayang diperoleh adalah sebesar 0,39 yang artinya rata-rata hasil belajar matematika siswa setelah pembelajaran dengan model TPS berada dalam kategori sedang.

Berdasarkan hasil uji hipotesis data hasilbelajar matematika siswa, terlihat bahwa terjadi peningkatanhasilbelajar matematikasecara signifikan. Berdasarkan hasil uji t diperoleh nilai t hitung lebih besar dari nilai $t$ tabel ${ }_{(0,05 ; 35)}$ yakni $\left(t_{\text {hitung }}=15,274>\right.$ $\left.\mathrm{t}_{\text {tabel }}=1,691\right)$ sehingga $\mathrm{H}_{0}$ ditolak. Sehingga dapat disimpulkan bahwaterdapat peningkatan hasil belajar matematika siswa dengan model pembelajaran TPS.

$$
\text { Peningkatan hasil belajar }
$$

matematika disebabkan oleh model pembelajaran yang diberikan pada siswa adalah model pembelajaran TPS yang memberikan kebebasan kepada siswa untuk mengembangkan berbagai cara penyelesaian masalah. Hasil analisis juga menunjukan bahwa sebagian besar pengaruh penerapan model pembelajaran TPSdalam meningkatkan hasil belajar matematika siswa berada dalam klasifikasi sedang dan masih ada yang berada dalam klasifikasi rendah.

Sesuai dengan pendapat Trianto (2009:59) tujuan dari model TPS adalah untuk meningkatkan kinerja siswa dalam tugas-tugas akademik, membantu siswa dalam memahami konsep-konsep yang sulit dan membantu siswa dalam menumbuhkan kemampuan berpikir kritis.Berkaitan dengan hal tersebut, maka dapat dikatakan bahwa model pembelajaran TPSmemiliki potensi besar untuk meningkatkan hasilbelajar matematika siswa SMP. Hal ini tentunya akan berdampak pada peningkatan mutu hasil belajar matematika siswa yang sangat diharapkan dalam pendidikan.

\section{Simpulan dan Saran}

\section{Simpulan}

Berdasarkan hasil penelitian dan pembahasan, maka dapat dikemukakan beberapa kesimpulan sebagai berikut:

1) Hasil belajar matematika siswa kelas VII $_{G}$ SMP Negeri 2 Kendari sebelum pembelajaran dengan menggunakan model pembelajaran TPS tergolong rendah. Dari hasil pre test terlihat bahwa rata- rata nilai tes hasil belajar matematika siswa hanya mencapai 42,66 dengan median 42,53 dan modus atau nilai yang sering muncul 42,53. Nilai minimum yang diperoleh adalah 26,44 dan nilai maksimum adalah 71,26. Selanjutnya jika dilihat dari nilai KKM tampak bahwa masih banyak siswa yang memperoleh nilai dibawah nilai KKM.

2) Hasil belajar matematika siswa setelah pembelajaran dengan menggunakan model pembelajaran TPS kelas $\mathrm{VII}_{\mathrm{G}}$ SMP Negeri 2 Kendari tergolong tinggi.Dari hasil post testterlihat bahwa rata-rata nilai tes hasil belajar matematika siswa sudah mencapai 65,58 dengan median 66,67 dan modus 67,82. Nilai minimum yang diperoleh adalah 49,43 dan nilai maksimum adalah 83,91. 
Selanjutnya jika dilihat dari nilai KKM tampak bahwa telah banyak siswa yang memperoleh nilai diatas nilai KKM.Secara umum hasil belajar matematika siswa mengalami peningkatan setelah pembelajaran dengan menggunakan model pembelajaran TPS.

3) Terdapat peningkatanhasilbelajarmatematika siswa dengan menggunakan model pembelajaran TPS, dengan yang mendapat kriteria rendah 11 siswa, sedangkan sebanyak 23 siswa, dan tinggi 1 siswa.

\section{Saran}

Berdasarkan kesimpulan di atas, saran yang dapat diberikan sebagai berikut:

1. Kepada para guru yang mengajar mata pelajaran matematika sekiranya dapat menggunakan model pembelajaran TPS sebagai salah satu alternatif model pembelajaran dalam pembelajaran matematika untuk mengoptimalkan hasil belajar matematika siswa.

2. Kepada para guru untuk lebih memperhatikan aspek mengidentifikasi terutama masalahmasalah dalam bentuk gambar dan juga memperhatikan kemampuan siswa dalam operasi perkalian dan pembagian untuk menunjang kemampuan memecahkan masalah.

3. Bagi peneliti yang hendak mengembangkan penelitian ini dapat melakukannya pada materi atau pokok bahasan lainnya dalam upaya hasil belajar matematika siswa, khususnya pelajaran matematika.

\section{Daftar Pustaka}

Asep Jihad dan Abdul Haris. (2010). Evaluasi Pembelajaran. Yogyakarta: Multi Presindo Yogyakarta.

Aunurrahman. (2009). Belajar dan Pembelajaran. Bandung: Alfabeta.

Bambang Warsita. (2008). Teknologi Pembelajaran Landasan dan Aplikasinya. Jakarta: PT. Rineka Cipta.

Duda, Hilarius Jago. (2010). Pembelajaran Berbasis Praktikum dan Asesmennya pada Konsep Sistem Ekskresi untuk Meningkatkan Kemampuan Berpikir Kritis Siswa Kelas XI. STKIP Persada Khatulistiwa Sintang: Kalimantan Barat. VOX Edukasi Vol. 1, N0. 2, Juli 2010. [online]. Tersedia di: http://isjd.pdii.lipi.go.Id/admin/jurna l/12103040_2086-4450.pdf. [5 Januari 2014].

Huda, M. (2011). Cooperative Learning Metode, Teknik, Struktur dan Model Penerapan. Yogyakarta: Pustaka Belajar

Huda, Miftahul. (2010). Cooperative Learning. Yogyakarta: Pustaka Pelajar.Rahayu

Karyasa, I Wayan dkk. (2011). Filsafat Ilmu. Singaraja: Undiksha Press.

Slavin, Robert E. (2011). Psikologi Pendidikan: Teori dan Praktik.Terjemahan Marianto Samosir. Educational Psychology: Theory and Practice. 2009. Jakarta: Indeks.

Suparno, Paul. (1997). Filsafat Konstruktivisme dalam Pendidikan.Yogyakarta: Kanisius. 